\title{
Antioxidant Activity and Lipoxygenase Inhibition Test with Total Flavonoid Content from Garcinia kydia Roxburgh Leaves Extract
}

\author{
Nur Laily Putri, Berna Elya*, Nuraini Puspitasari
}

Nur Laily Putri, Berna Elya*,

\section{Nuraini Puspitasari}

Department of Pharmacognosy-

Phytochemistry, Faculty of Pharmacy,

Universitas Indonesia, Kampus Baru UI

Depok 16424, Depok, INDONESIA.

\section{Correspondence}

\section{Berna Elya}

Department of Pharmacognosy-Phytochemistry, Faculty of Pharmacy, Universitas Indonesia, Kampus Baru UI Depok 16424, Depok, INDONESIA.

Phone. +62 217270031.

Email: berna.elya@gmail.com

\section{History}

- Submission Date: 21-12-2016;

- Review completed: 05-01-2017;

- Accepted Date: 16-01-2017.

\section{DOI : 10.5530/pj.2017.2.48}

Article Available online

http://www.phcogj.com/v9/i2

\section{Copyright}

(C) 2017 Phcog.Net. This is an openaccess article distributed under the terms of the Creative Commons Attribution 4.0 International license.

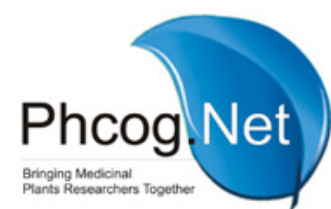

\begin{abstract}
Introduction: Antioxidant is one of the therapeutic strategies to overcome oxidative stress and inhibit synthesis of inflammatory mediators through lipoxygenase pathway. Garcinia is the largest of Clusiaceae family which has been proven to provide antioxidant and anti-inflammatory activity. Garcinia kydia Roxburgh is one of the plants of this genus which is known to have antioxidant activity but lipoxygenase inhibition activity from this plant was unknown. Methods: This study aimed to test antioxidant activity of the methanol, ethyl acetate and n-hexane extract from Garcinia kydia Roxburgh leaves by FRAP (Ferric Reducing Antioxidant Power) method, anti-inflammatory activity was tested by inhibiting lipoxygenase and total flavonoid content by colorimetric methods AlCl3. Results: The results showed an antioxidant activity of methanol extract, ethyl acetate and $n$-hexane leaves of Garcinia kydia Roxburgh have $\mathrm{EC}_{50}$ value, respectively 18,$448 ; 12,389$ and $31,260 \mu \mathrm{g} / \mathrm{mL}$, and the lipoxygenase inhibition activity have $I C_{50}$ value, respectively 0,$556 ; 0,212$ and $3,575 \mu \mathrm{g} / \mathrm{mL}$. Ethyl acetate extract of Garcinia kydia Roxburgh leaves was the most active extract in this study which has total flavonoid content, 30,650 mgQE/ gram extract. Conclusion: The conclusion, Garcinia kydia Roxburgh has antioxidant and lipoxygenase inhibition activity, with ethyl acetate extract as the most active extract which contains total flavonoids.
\end{abstract}

Key words: Antioxidant, Flavonoid content, FRAP, Garcinia kydia Roxburgh, Lipoxygenase.

\section{INTRODUCTION}

Free radicals can cause oxidative stress. Oxidative stress related to the pathogenesis of inflammatory because it can induce the synthesis of inflammatory mediators. ${ }^{1}$ Lipoxygenase is an enzyme which involved in the biosynthesis of inflammatory mediators such as leukotrienes which play an important role in the development of inflammatory diseases such as asthma. ${ }^{2}$ Therefore, research on the compound to prevent the synthesis of inflammatory mediators through the lipoxygenase continue to do. An antioxidant is used as a therapeutic strategy to overcome oxidative stress and inflammatory diseases. ${ }^{3,4}$ Some plants are known to have antioxidant activity, such as Garcinia. Garcinia is the largest genus of Clusiaceae which has 400 species and 77 species among them are found in Indonesia. ${ }^{5}$ Every part of Garcinia like fruit, flowers, leaves, and stems are widely used to treat inflammation and oxidative stress ${ }^{6}$ and also Garcinia mostly contain xanton, benzophenone, and mangosteen which has antibacterial, antioxidant and antiinflammatory activity, so Indonesia has a big chance to explore the plant Garcinia as herbal medicine.

Previous antioxidant study on Garcinia showed that methanol extract, ethyl acetate and n-hexane leaves of Garcinia atroviridis could scavenge radical 1,1-diphenyl-2-picrylhydrazyl (DPPH) respectively 57,97; 59,18 and $55,67 \% .^{7}$ Garcinia also has anti-inflammatory activity. Study about anti-inflammatory activity on Garcinia nervosa leaves and stems extract showed the percentage lipoxygenase inhibition activity, respectively for 86.53 and $62,54 \%{ }^{8}$

This study aimed to investigate Garcinia kydia Roxburgh. The leaves of this plant are used traditionally as antitumor and anti-inflammatory. The previous study showed that leaves of Garcinia kydia Roxb. using DPPH method on methanol extract, ethyl acetate, and n-hexane have antioxidant activity. The most-active extracts from these studies were ethyl acetate extract with $\mathrm{IC}_{50} 11,06 \mu \mathrm{g} / \mathrm{Ml} .{ }^{10}$ The objective of this research was to study antioxidant and lipoxygenase inhibition activity from Garcinia kydia Roxb. leaves extract.

\section{MATERIALS AND METHODS}

\section{Materials}

Methanol, ethyl acetate, and n-hexane leave extract of Garcinia kydia Roxb. Are obtained from Laboratory of Phytochemistry and Pharmacognosy, Faculty of Pharmacy, University of Indonesia.

Ferric Reducing Antioxidant Power(FRAP) Assay

The ferric reducing power of Garcinia kydia extracts was performed using a modified version of FRAP assay. ${ }^{11}$ This reduction was measured using Spectrophotometer UV-Vis (PG Instruments Ltd T80) at 596 $\mathrm{nm}$. The stock FRAP reagent was prepared daily by mixing 1 volume $10 \mathrm{mM}$ TPTZ (2,4,6-tripyridyl-striazine) solution in $40 \mathrm{mM} \mathrm{HCl}$, with 1 volume $\mathrm{mL}$ 
$20 \mathrm{mM} \mathrm{FeCl}_{3} \cdot 6 \mathrm{H}_{2} \mathrm{O}$ solution and 10 volume $300 \mathrm{mM}$ acetate buffer $\mathrm{pH}$ 3,6.Baicalein used as positive control. For the test, $0,2 \mathrm{~mL}$ sample test solution were allowed to react with $3,8 \mathrm{~mL}$ of the FRAP solution for 30 minutes at $37^{\circ} \mathrm{C}$ in the incubator. For the control, the sample contained $0,2 \mathrm{~mL}$ ethanol and 3,8 $\mathrm{mL}$ FRAP solutions. Readings the absorbance of colored product $\left(\mathrm{Fe}^{2+}-\mathrm{TPTZ}\right.$ complex) at $596 \mathrm{~nm}$. Antioxidant capacity was evaluated by calculating the production of $\mathrm{Fe}^{2+}$-TPTZ complex. $\%$ antioxidant capacity $=(1-\mathrm{Ts}) \times 100 \%$. Where Ts is transmittance, As $=-\log \mathrm{Ts}$ and As is derived from sample absorbance - control sample absorbance.

\section{Lipoxygenase Inhibition Test}

Enzyme activity was measured using Spectrophotometer UV-Vis (PG Instruments Ltd T80) at $235 \mathrm{~nm}$ and $25^{\circ} \mathrm{C}$ after addition of boric acid $200 \mathrm{mM}$ pH 8,5, lipoxygenase $(375 \mathrm{U} / \mathrm{mL}$, final concentration), using linoleic acid $(225 \mu \mathrm{M}$, final concentration) as a substrate, and methanol as stop solution. Baicalein was employed as a positive control. For the test, 1,69 $\mathrm{mL}$ boric acid and $1 \mathrm{~mL}$ linoleic acid was preincubated with $0,01 \mathrm{~mL}$ sample test solution for 10 minutes at $25^{\circ} \mathrm{C}$, followed by addition of $0,3 \mathrm{~mL}$ lipoxygenase and was incubated again for $15 \mathrm{~min}$ utes at $25^{\circ} \mathrm{C}$. Enzyme reaction was terminated by the addition of $1 \mathrm{~mL}$ methanol to the final volume of $4 \mathrm{~mL}$ and absorbance of product reaction HPOD was measured at $235 \mathrm{~nm}$.For the sample control, only boric acid, linoleic acid, boric acid and methanol. Blanks contained boric acid, linoleic acid, lipoxygenase, and methanol. For the blanks, control contained boric acid, linoleic acid, and methanol were pipetted into the cuvette. The lipoxygenase inhibitory activity was evaluated by calculating the percentage of the inhibition of HPOD production from the changes in absorbance values. \% inhibition $=\left[\left(A_{b}-A_{b c}\right)-\left(A_{e}-A_{e c}\right)\right] \times 100 /\left(A_{b}-A_{b c}\right)$. Where $A_{b}$ is the absorbance of control, $A_{b c}$ is the blanks control, $A_{e}$ is the absorbance of sample and $\mathrm{A}_{\mathrm{ec}}$ is the absorbance of sample control.

\section{Thin Layer Chromatography (TLC) Profile}

To activate the plates, silica gel $60 \mathrm{~F}_{254} 20 \times 20 \mathrm{~cm}$ was heated at $105^{\circ} \mathrm{C}$ for 30 minutes in the oven before used. Chamber was saturated using mobile phase of each extract. An optimum mobile phase used for methanol, ethyl acetate, and n-hexane leaves extract of Garcinia kydia Roxb. respectively ethyl acetate - formic acid (20: 1), toluene - ethyl acetate - formic acid (61:30: 9) and n-hexane - ethyl acetate (6: 4). For the test, $10 \mathrm{mg} / \mathrm{mL}$ sample test solution was spotted on TLC plates using $1 \mu \mathrm{L}$ microcapillary tube. The plates were eluted by mobile phase after elution was completed the plates were dried in the air and extract spots were observed with visible light of short wavelength ultraviolet $(254 \mathrm{~nm})$ and longwave (366 $\mathrm{nm})$. Then the plates were sprayed with $\mathrm{AlCl}_{3}$ to $5 \%$ and $\mathrm{Rf}$ values were counted.

\section{Flavonoid Content}

The assay was performed according to a previously described procedure. ${ }^{12}$ Flavonoid in methanol, ethyl acetate and n-hexane leaves extract of Garcinia kydia Roxb. were estimated as Quercetin equivalent. Quercetin was used to make the calibration curve. For the test, $0,5 \mathrm{~mL}$ sample test solution were mixed with $1,5 \mathrm{~mL}$ methanol, $0,1 \mathrm{~mL}$ aluminium chloride $10 \%, 0,1 \mathrm{~mL}$ sodium acetate $1 \mathrm{M}$ and $2,8 \mathrm{~mL}$ distilled water. The volume of aluminium chloride was substituted by the same volume of distilled water in blank. After incubation at room temperature for 30 minutes, the absorbance of the reaction mixture was measured at 435 $\mathrm{nm}$. From the calibration curve of quercetin, concentration values of all extracts and total flavonoid content was calculated by using formula, $\mathrm{TFC}=(\mathrm{R} \times \mathrm{DF} \times \mathrm{V} \times 100) / \mathrm{W}$. Where $\mathrm{R}$ is the result obtained from standard curve $(\mathrm{mg} / \mathrm{mL}), \mathrm{DF}$ is dilution factor, $\mathrm{V}$ is volume of stock solution $(\mathrm{mL})$, and $\mathrm{W}$ is weight of extract used in sample test (gram). ${ }^{13}$

Statistical analysis All values obtained were analyzed statistically using Microsoft Office Excel 2013 and Graphpad Prism 7.

\section{RESULTS AND DISCUSSION}

\section{Antioxidant Activity}

The FRAP assay is the only assay that directly measures antioxidants or reductants in a sample. The other assays are more indirect because they measure the inhibition of reactive species (free radicals) generated in the reaction mixture, and these results also depend strongly on the type of reactive species used. ${ }^{14}$

The principle of the test using FRAP method measures the ability of an antioxidant to reduce $\mathrm{Fe}^{3+}$ in the complex TPTZ to $\mathrm{Fe}^{2+}$. The reduction reaction is shown by baicalein solution and extracts were initially yellowish colored clear solution when mixed with FRAP, the mixture solution became blue and blue more intense after incubation. If the sample reduces $\mathrm{Fe}^{3+}$ to $\mathrm{Fe}^{2+}$, at the same time sample will be oxidized, so sample can act as an antioxidant. ${ }^{15}$

Baicalein was used as a positive control because it has catecholic alcohol to ligate the iron of lipoxygenase and cause an inner sphere reduction on the active site iron, with baicalein undergoing oxidation to its quinone form. The result showed $\mathrm{EC}_{50}$ baicalein was $1,165 \mu \mathrm{g} / \mathrm{mL}$. So, baicalein

\begin{tabular}{lccc}
\multicolumn{6}{l}{ Table 1: Calibration curve and EC $_{50}$ values of baicalein and extract } \\
\hline No & Sample & Calibration Curve & EC50 $(\mu \mathrm{g} / \mathrm{mL})$ \\
\hline 1 & Baicalein & $\mathrm{y}=17,663+27,756 \mathrm{x}, \mathrm{r} 2=0,992$ & 1,165 \\
2 & Methanol Extract & $\mathrm{y}=22,893+1,4694 \mathrm{x}, \mathrm{r} 2=0,9789$ & 18,448 \\
3 & Ethyl acetate extract & $\mathrm{y}=18,629+2,5321 \mathrm{x}, \mathrm{r} 2=0,9855$ & 12,389 \\
4 & n-Hexane extract & $y=\frac{100}{\left(1+10^{\left.(1,495-X)^{* 1,784}\right)}, \mathrm{r}^{2}=0,9897\right.}$ & 31,260
\end{tabular}

\begin{tabular}{lccc}
\multicolumn{5}{l}{ Table 2: Calibration curve and $\mathbf{E C}_{\mathbf{5 0}}$ values of baicalein and extracts } \\
\hline No & Sample & Calibration Curve & IC50 $(\mu \mathrm{g} / \mathrm{mL})$ \\
\hline 1. & Baicalein & $\mathrm{y}=5,9918+186 \mathrm{x}, \mathrm{r} 2=0992$ & 0,237 \\
2. & Methanol Extract & $\mathrm{y}=-13,545+114,33 \mathrm{x}, \mathrm{r} 2=0,9756$ & 0,556 \\
3. & Ethyl acetate extract & $y=\frac{100}{\left(1+10^{(-0,6728-X)+3,954)}, \mathrm{r}^{2}=0,9868\right.}$ & 0,212 \\
& & $y=\frac{100}{\left(1+10^{(0,5532-X)+2,287}\right)}, \mathrm{r}^{2}=0,9773$ & 3,575 \\
\hline
\end{tabular}




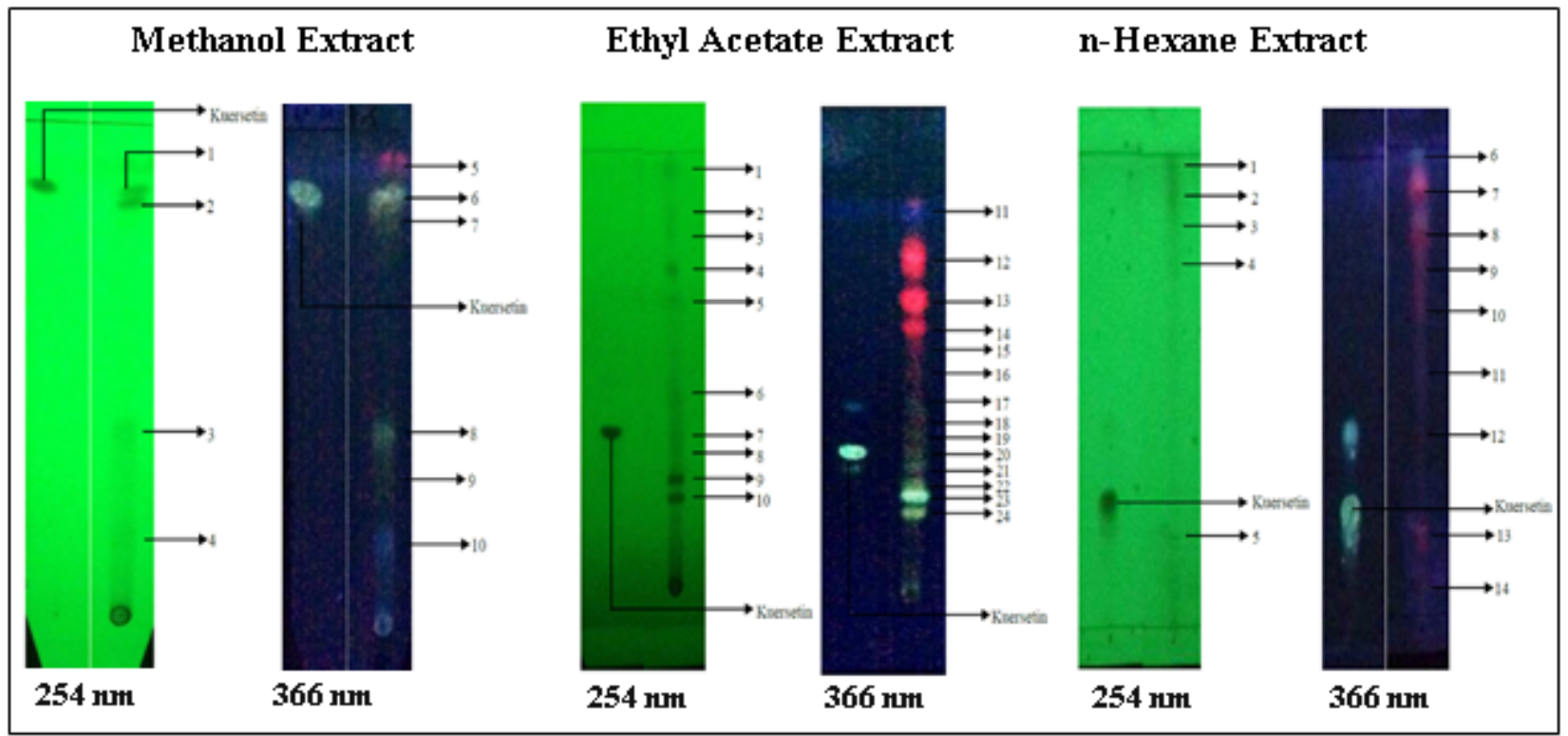

Figure 1: Chromatogram quercetin and Garciniakydia Roxb leaves extract.

was classified as a very strong antioxidant because the value of $\mathrm{EC}_{50}<50$ $\mu \mathrm{g} / \mathrm{mL} .^{15}$

Antioxidant activity test showed that methanol, ethyl acetate, and n-hexane leaves extract of Garcinia kydia Roxb. had $\mathrm{EC}_{50}$ respectively 18,448; 12,389 and $31,260 \mu \mathrm{g} / \mathrm{mL}$. These results indicate that all extract has very strong antioxidant activity (Table 1 ). ${ }^{15}$

Based on phytochemical screening conducted on Garcinia kydia Roxb. leaves extract showed that methanol extract contained several secondary metabolites, such as alkaloids, flavonoids, tannins, anthraquinone, and saponin; ethyl acetate extract contained alkaloids, flavonoids, and terpenoids; as well as n-hexane extract contained terpenoids. ${ }^{10}$ Flavonoids and tannins classified into phenolic compounds. In general, phenolic compounds having one or more aromatic rings with one or more hydroxyl groups. Their antioxidant activity will increase if they have more free hydroxyl groups and bond conjugation in the aromatic ring. Antioxidant potency of phenolic compounds is associated with the ability to donate electrons, reduce and chelate metal ions. ${ }^{16}$ The largest group of phenolic compounds are flavonoid. Flavonoid has an $\mathrm{OH}$ group at the ortho position C 3, 4, 3, keto group at C4, the double bond at the $\mathrm{C} 2$ and $\mathrm{C} 3$ which has high antioxidant capacity. $\mathrm{OH}$ group in the ortho position C3'- C4' have the highest impact on the antioxidant capacity of flavonoids because it can be used to donate $\mathrm{H}$ atoms in free radicals. ${ }^{15}$ In addition to phenolic compounds, indole alkaloids such groups also have antioxidant activity. Alkaloid compounds can stop free radical chain by donating $\mathrm{H}$ atoms in free radicals. ${ }^{17}$ Then, the anthraquinone compounds are known to have antioxidant activity through reducing the hydroxyl radical. ${ }^{18}$ Tetraterpen compounds such as terpenoids and carotenoids have antioxidant activity both in vitro and in vivo. ${ }^{16}$ The main mechanism of carotenoids as antioxidants is reverse the singlet oxygen and donates electrons or hydrogen. ${ }^{19}$ Based on these studies, it is known that secondary metabolites such as alkaloids, flavonoids, tannins, anthraquinone, and terpenoids have antioxidant activity. Therefore, it can be estimated that compounds contribute to an antioxidant activity held Garcinia kydia Roxb. leaves extract.

\section{Lipoxygenase Inhibition}

The principle of this study was inhibited lipoxygenase activity to form hydroperoxide compound which plays important roles in the development of acute inflammation. ${ }^{20}$ The product reaction between lipoxygen- ase and linoleic acid is hydroperoxyoctadecadienoat (HPOD). Iron in lipoxygenase is involved in electron transfer during the process of insertion of oxygen into unsaturated fatty acids containing cis, cis-1,4-pentadiene. Lipoxygenase in the oxidized form $\left(\mathrm{Fe}^{3+}\right)$ can catalyze the release of the hydrogen atoms of the C-11 methylene group in linoleic acid to form a radical pentadiene and reduced lipoxygenase $\left(\mathrm{Fe}^{2+}\right)$, under aerobic conditions these radicals react with dioxygen to a hydroperoxy radical. As a result of the oxidation of $\mathrm{Fe}^{2+}$ to $\mathrm{Fe}^{3+}$, fatty acids are formed into 13-hydroperoxy-9 (Z), 11 (E) -octadecadienoat (13(S)-HPOD). ${ }^{20,21,22}$

The results showed baicalein $\mathrm{IC}_{50}$ was $0.237 \mu \mathrm{g} / \mathrm{mL}$, whereas in the previous study the value of $\mathrm{IC}_{50}$ obtained was $0.324 \mu \mathrm{g} / \mathrm{mL}$ (Table 2). ${ }^{23}$ Baicalein acted as an inhibitor which inhibits the oxidation of linoleic acid into HPOD.Baicalein have a catechol group that can bind iron and lead reduction in the active site of iron lipoxygenase so baicalein undergo oxidation to form quinones and the enzyme can not react with the substrate to form leukotrienes. ${ }^{24}$

The test results showed that methanol, ethyl acetate, and n-hexane leaves extract of Garcinia kydia Roxb. have $\mathrm{IC}_{50}$ respectively 0,556; 0,212 and $3,575 \mu \mathrm{g} / \mathrm{mL}$. These results indicate that the three extracts could inhibit lipoxygenase activity. Ethyl acetate extract was the most active extracts that have the lowest $\mathrm{IC}_{50,}, 0,212 \mu \mathrm{g} / \mathrm{mL}$. Phytochemical screening ever conducted, showed that the ethyl acetate extract contains alkaloids, flavonoids, and terpenoids. Therefore, it is thought that the presence of such compounds has a synergistic effect in lipoxygenase inhibition activity from ethyl acetate extract. ${ }^{25}$

Based on phytochemical screening conducted on Garcinia kydia Roxb. leaves extract showed that methanol extract contained secondary metabolites such as alkaloids, flavonoids, tannins, anthraquinone, and saponin; ethyl acetate extract contains alkaloids, flavonoids, and terpenoids; as well as n-hexane extract contains terpenoids. ${ }^{10}$ Based Chedea and Jisaka, polyphenol compounds such as flavonoids and tannins can inhibit lipoxygenase activity. Flavonoids such as flavonols have a catechol group that can form complexes with $\mathrm{Fe}^{3+}$ on an enzyme. Other flavonoids such as isoflavones can inhibit lipoxygenase activity with donating electrons. This causes the electron donor $\mathrm{Fe}^{3+}$ on enzyme become reduced to its inactive form $\left(\mathrm{Fe}^{2+} \cdot{ }^{26}\right.$ Terpenoids compounds such as carotenoids also inhibit lipoxygenase activity by keeping the iron in the enzyme in its inactive form $\left(\mathrm{Fe}^{2+}\right.$. In addition to these compounds, it is known that the alkaloid and anthraquinone can also inhibit lipoxygenase activity. ${ }^{27,28}$ 
Based on these studies, it is known that secondary metabolites such as alkaloids, flavonoids, tannins, anthraquinone, and terpenoids can inhibit lipoxygenase activity. Therefore, it can be estimated that compounds contribute to the inhibition of lipoxygenase activity which is owned by the leaf extract of Garcinia kydia RoxbTLC Profile (Figure 1).

TLC profile aimed to determine the most flavonoid content on extracts qualitatively and supports antioxidant and lipoxygenase inhibition activity result. Chromatogram has sprayed by $\mathrm{AlCl}_{3}$ will react with the keto group in the $\mathrm{C} 4, \mathrm{C} 5$ and $\mathrm{OH}$ group on ortho position to form yellow complex compounds. ${ }^{29}$ The results showed that methanol and ethyl acetate extract have a yellow spot. The conclusion, both extracts contained flavonoid and ethyl acetate extract has more yellow spots than methanol extract. So, flavonoid content on ethyl acetate extract would be counted quantitatively.

\section{Total Flavonoid Content}

Flavonoid content assay was performed to determine total flavonoids content in the most active extract. The most-active extract is an extract which has the highest antioxidant and lipoxygenase inhibition activity. Most active extracts obtained from the study was ethyl acetate extract. Total flavonoid assay was tested by colorimetric methods $\mathrm{AlCl}_{3}$ with quercetin as a positive control. $\mathrm{AlCl}_{3}$ can form a stable complex with $\mathrm{C} 4$ keto group and a hydroxyl group at $\mathrm{C} 3$ and $\mathrm{C} 5$ of flavones and flavonols. In addition, $\mathrm{AlCl}_{3}$ can form labile complexes with orto-dihydroxyl group in ring $\mathrm{A}$ and $\mathrm{B}$ flavonoid. ${ }^{30} \mathrm{~B}$ ased on the results, quercetin calibration curve, $\mathrm{y}=0.1393+0,0434 \mathrm{x}, \mathrm{R}^{2}=0,9957$ and 1 gram of ethyl acetate extract contain $30,65 \mathrm{mg}$ quercetin equivalents.

\section{CONCLUSION}

Garcinia kydia Roxburgh leaves extract has antioxidant and lipoxygenase inhibition activity, with ethyl acetate extract as the most active extract which contains a total flavonoid.

\section{ACKNOWLEDGMENT}

Thanks to PITTA Grant University of Indonesia that funding this research.

\section{CONFLICT OF INTEREST}

No conflict of interest are declared.

\section{REFERENCES}

1. Closa D, Folch-Puy E. Critical review: Oxygen free radicals and the systemic inflammatory response systemic inflammatory response. IUBMB Life. 2004;56(4):185-91

2. Ling SK, Tanaka T, and Kouno I. Effects of iridoids on lipoxygenase and hyaluronidase activities and their activation by beta-glucosidase in the presence of amino acids. Biological dan Pharmaceutical Bulletin. 2003;26(3):352-6. http:// doi.org/10.1248/bpb.26.352.

3. Lobo V, Patil A, Phatak A, Chandra N. Free radical, antioxidants and functional foods: Impact on human health. Pharmacognosy Reviews. 2010;4(8):118-26

4. Yun-Hsiang $\mathrm{C}$, Wang $\mathrm{PH}$, Sriboonlue $\mathrm{P}$, Yuh-Lien C. Antioxidative strategy for inflammatory diseases. Mediators of Inflammation, 2015, http://dx.doi. org/10.1155/2015/675816.

5. Sulassih S, Santosa E. Phylogenetic analysis of mangosteen (Garcinia mangostana L.) and its relatives based on morphological and inter simple sequence repeat (ISSR) markers. Sabrao Journal. 2013;45(3):478-90

6. Hemshekhar M, Sunitha K, Sebastin Santhosh M, Devaraja S, Kemparaju K, Vishwanath BS, et al. An overview on genus garcinia: phytochemical and therapeutical aspects. Phytochemical Review. 2010;10:325-51.
7. Abdullah AR, Bakhari NA, Osman H. Study on relationship of the phenolic, flavonoid and tannin content to the antioxidant activity of Garcinia atroviridis. Universal Journal of Applied Science. 2013;1(3):95-100.

8. Seruji NMU, Khong HY, Kutoi CJ. Antioxidant, anti-inflammatory, and cytotoxic activities of Garcinia nervosa (Clusiaceae). Journal of Chemistry. 2013; pp 1-5.

9. Mahabusarakam W, Chairerk P, Taylow WC. Xanthones from Garcinia cowa Roxb. latex. Journal of Phytochemistry. 2005;66:1148-53

10. Elya B, Basah K, Mun'im A, Hasiholan A, Marlin I, Mely M. Antioxidant Activities Of Leaves Extracts Of Three Species Of Garcinia. International Journal Medication of Aromatic Plants. 2012;2(4):691-3.

11. Chanda S, Dave R. In vitro models for antioxidant activity evaluation and some medicinal plants possessing antioxidant properties: An overview. African Journal of Microbiology Research. 2009;3(13):981-96.

12. Singh T, Kasture SB, Mohanty PK, Jaliwala Y, Manvedra SK. In vitro antioxidative activity of phenolic and flavonoid compounds extracted from fruit of Garcinia indica. International Journal of Pharmaceutical and Life Science. 2011;2(3).

13. BhaigyabatiT, Devi PG, Bag G. Total flavonoida content and antioxidant activity of aqueous rhizome extract of three hedychium species of manipur valley. Research Journal of Pharmaceutical, Biological, and Chemical Sciences. 2014;5(5):970-6.

14. Halvorsen BL, Holte K, Myhrstad MCW, Barikmo I, Hvattum E, Remberg SF, et al. A systematic screening of total antioxidants in dietary plants. American Society for Nutritional Sciences. 2002;132:461-71.

15. Fidrianny I, Aristya T, Hartati R. Antioxidant capacities of various leaves extracts from three species of legumes and correlation with total flavonoida, phenolic, carotenoid content. International Journal of Pharmacognosy and Phytochemical Research. 2015;7(3);628-34.

16. Kasote DM, Katyare SS, Hegde, Mahabaleshwar V, Bae H. Significance of antioxidant potential of plants and its relevance to therapeutic applications. International Journal of Biological Sciences. 2015;11(2);982-91.

17. Zahari, Azeana. Ablat, Abdulwali., Sivasothy, Yasodha., Mohamad, Jamaludin., Choudhary, MI, dan Khalijah Awang. In vitro antiplasmodial and antioxidant ac tivities of bisbenzylisoquinoline alkaloids from Alseodaphne corneri Kosterm. Asian Pacific Journal of Tropical Medicine. 2016;9(4):328-32.

18. Yen GC, Duh PD, Chuang DY. Antioxidant activity of anthraquinones and anthroen. Food Chemistry. 2000;70(4):437-41.

19. Grabmann J. Terpenoid as plant antioxidants. Vitamin and Hormones 2005;72:505-35.

20. Chedea VS, Ioana S, Socaciu C, Nagaya T, Joseph H, Ogola O. Lipoxygenasequercetin interaction: A kinetic study through biochemical and spectroscopy approaches. Biochemical Testing. 2012;7:152-178. http://www.intechopen.com

21. Malekian F, Rao RM, Prinyawiwatkul W, Marshall WE. Lipase and lipoxygenase activity, functionality, and nutrient losses in rice bran during storage. LSU Agricultural Center Research and Extension, 2000.

22. Elshof MBW, Veldink, Janssen GA, Vliegenthart JFG. Biocatalytic large-scale production of 13(S)-hydroperoxy-9(Z), 11(E) -octadecadienoic acid from hydrolised safflower oil by a crude soybean-flour extract as lipoxygenase source. Recl Trav Chim Pays-Bass 115. 1996;499-504.

23. Schomburg and Schomburg. Class 1 Oxidoreductase X. In Springer Handbook of Enzyme Springer, Berlin. 2007;25(2):593-5.

24. Deschamps JD, Kenyon, Victor A, Theodore $\mathrm{RH}$. Baicalein is a potent in vitro inhibitor against both reticulocyte 15-human and platelet 12-human lipoxygenases. Bioorganic dan Medicinal Chemistry. 2006;14:4295-301.

25. Fofana S, Gnoula C, Moussa O, Pale E, Nebie RHC, Nikiema JB, et al. DPPH radical scavenging and lipoxygenase inhibitory effects in extract from Erythrina senegalensis (Fabaceae) DC. African Journal of Pharmacy and Pharmacology. 2016;10(11):185-91.

26. Chedea VS and Jisaka M. Inhibition of soybean lipoxygenases - structural and activity models for the lipoxygenase isoenzymes family. Recent Trends for Enhancing the Diversity and Quality of Soybean Products. 2011;28:110-30. http:// www.intechopen.com

27. Rackova L, Oblozinsky M, Kostalova D, Kettmann V, Lydia B. Free radical scavenging activity and lipoxygenase inhibition of Mahonia aquifolium extract and isoquinoline alkaloids. Journal of Inflammation London. 2007;4:15.

28. Dzoyem JP, Donfack AR, Tane P, McGaw LJ, loff JN. Inhibition of nitric oxide production in Ips-stimulated raw 264,7 macrophages and 15-lox activity by anthraquinones from Pentas schimperi. Planta Medica, I(8). 2016. http://doi. org/10.1055/s-0042-104417.

29. Andersen OM dan Kenneth RM. Flavonoids: Chemistry, Biochemistry, and Applications. New York: Taylor \& Francis, 2006;18.

30. Chang C, Yang M, Wen H, dan Chern J. Estimation of total flavonoida content in propolis by two complementary colorimetric methods. Journal of Food and Drug Analysis. 2002:10(3):178-82. 


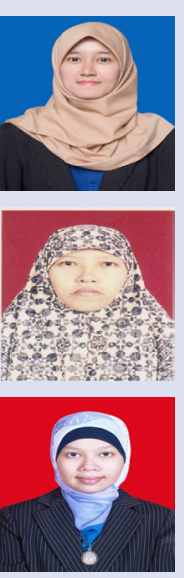

\section{ABOUT AUTHORS}

Nur Laily Putri: Undergraduate Student from Faculty of Pharmacy, University of Indonesia Enrolling Apothecary Program in Faculty of Pharmacy University of Indonesia

Elya: Lecturer, Supervisor, and Laboratory of Phytochemistry and Pharmacognos, Faculty of Pharmacy, Universitas Indonesia.

Puspitasari: Lecturer, Supervisor, and Laboratory of Phytochemistry and Pharmacognos, Faculty of Pharmacy, Universitas Indonesia,

Cite this Article: Putri NL, Elya B, Puspitasari N. Antioxidant Activity and Lipoxygenase Inhibition Test with Total Flavonoid Content from Garcinia kydia Roxburgh Leaves Extract. Pharmacogn J. 2017;9(2):280-4. 